\title{
OMENIREA ÎNGRIJORATĂ DE STAREA SĂNĂTĂṬII PLANTELOR
}

\author{
${ }^{1}$ Voloșciuc L., ${ }^{2}$ Josu Veronica, ${ }^{3}$ Voloșciuc E. \\ ${ }^{I}$ Institutul de Genetică, Fiziologie și Protecție a Plantelor, \\ ${ }^{2}$ Ministerul Agriculturii, Dezvoltării Regionale și Mediului, \\ ${ }^{3}$ Universitatea „,Alexandru Ioan Cuza”, Iași, România \\ Chișinău, Republica Moldova, E-mail:1.volosciuc@gmail.com
}

\begin{abstract}
The United Nations has declared 2020 the International Year of Plant Health (IYPH), through Resolution 73/252, adopted on December 20, 2018 by the General Assembly. This is a unique opportunity to raise global awareness of how protecting plant health can help stop hunger, reduce poverty, protect the environment and stimulate economic development. The article explains the contradiction between humanity's view of the role of plants in the biosphere and their protection functions, when it becomes increasingly clear the need to change the paradigm of plant protection, which as a widely accepted mental construction, would provide the human community for a long time a consistent basis. for the substantiation of the new paradigm "Plant Health".
\end{abstract}

Key words: Biological preparations, Ecology, Ecological agriculture, Paradigm, Pathogens, Pests, Plant protection. 


\section{Introducere}

Pe fundalul fortificării securităţii alimentare și reducerii daunelor cauzate de organismele dăunătoare, impactul cărora atinge $25-30 \%$, iar în condiţiile dezvoltării epifitotice a patogenilor şi invaziei vertiginoase a dăunătorilor şi buruienilor, pierderile de recoltă depăşesc 50-60\% sau compromit complet culturile agricole, a devenit stringentă necesitatea elaborării mijloacelor eficiente de combatere a lor. În consecință poluarea, ca rezultat al aplicării pesticidelor, pune în pericol diversitatea biologică și existenţa a numeroase specii de plante şi animale. Drept reacție a sporirii impactului problemelor ecologice și agravării securității alimentare și siguranței alimentelor, Organizaţia Naţiunilor Unite pentru Alimentaţie şi Agricultură (FAO) a declarat anul 2020 "Anul Internaţional al Sănătăţii Plantelor". Aceasta reprezintă o ocazie unică pentru creşterea gradului de conştientizare la nivel global cu privire la modul în care protejarea sănătăţii plantelor poate contribui la stoparea foamei, reducerea sărăciei, protejarea mediului şi stimularea dezvoltării economice [9].

Fundamentarea acestei decizii istorice este determinată de rolul biosferic al plantelor și dinamica stării fitosanitare a lor pe parcursul ultimelor decenii. Plantele de cultură reprezintă sursa de oxigen din aerul respirat de omenire, precum și resursele alimentare principale. $\mathrm{Cu}$ toate acestea, omenirea adesea nu conștientizează esența fenomenelor naturale și antropice, ceea ce reduce eficiența acțiunilor primare orientate la păstrarea stării de sănătate a plantelor, creând premise pentru înregistrarea unei stări devastatoare. Schimbările climatice şi activităţile omului au afectat ecosistemele, reducând biodiversitatea şi creând noi nişe ecologice, în care se creează condiții favorabile pentru dezvoltarea agenților fitosanitari. În acelaşi timp, călătoriile şi comerţul internaţional s-au triplat în ultimul deceniu, ceea ce a accelerat răspândirea agenților patogeni ai bolilor și dăunătorilor de carantină şi a organismelor invazive, provocând astfel pagube considerabile pentru plantele de cultură şi mediu $[5,10]$.

În condițiile manifestării frecvente a contradicției dintre viziunea omenirii asupra rolului plantelor în biosferă și funcțiile protecției lor, devine tot mai evidentă necesitatea schimbării paradigmei protecției plantelor, care în calitate de construcție mentală larg acceptată, ar oferi comunității umane pe o perioadă îndelungată o bază consistentă pentru fundamentarea paradigmei noi "Sănătatea Plantelor", cu aparatul definitoriu adecvat, spectrul noțiunilor clare, gama viziunilor teoretice și noțiunile specifice pentru soluționarea problemelor apărute, precum și cadrul instituțional, componentele din structura strategiilor tehnologice, de extensiune și educaţionale [3]. Astfel, umanitatea va înregistra manifestarea rezilienței la factorii de risc și a capacităților sistemelor de a se adapta și înfrunta dificultățile într-o manieră pozitivă la situații nefavorabile, frecvența cărora sporește permanent.

\section{Material şi metode}

Pentru cercetare au fost utilizate insecte fitofage: Mamestra brassicae şi Heliothis armigera, Hyphantria cunea şi Lymantria dispar, sușe de baculovirusuri, bacterii și ciuperci antagoniste, nematozi entomopatogeni și alte organisme utile [10]. Testarea în condiţii de laborator şi în câmpul de experienţă a fost efectuată în 4 repetiții respectiv randomizate, în conformitate cu cerinţele generale ale experienţelor de acest gen [16].

Acumularea masei biologice necesită prezenţa agenților biologici, titrul cărora să depăşească $10^{8}$ part./ml, iar determinarea calităţii ei și a formelor preparative sa efectuat cu aplicarea mijloacelor de vizualizare și determinare a eficacității biologice, economice și ecologice. 
Cercetarea fazelor procesului de producere a bacteriofagilor include determinarea condiţiilor optimale şi a vârstei bacteriei-gazdă (Xanthomonas campestris) pentru inocularea lor cu particule bacteriofagice. La vârsta de 7-8 ore (a fost cercetat timpul de 6-11ore) bacteriile se infectează cu bacteriofagi, care se reproduc timp de 4-6 ore, iar apoi se determină titrul suspensiei virale obţinute, care ulterior se supune conservării [14].

Situația din domeniul protecției plantelor și mediului înconjurător a fost analizată prin aplicarea metodologiei abordărilor sistemice, ca instrument al managementului complexității și ca una dintre paradigmele esențiale ale viitorului conform postulatelor Niculescu M., Lavalette G. (1999), Савинов А.Б. (2005) [8, 18].

\section{Rezultate şi discuţii \\ Sporirea rolului ecosistemic și economic al plantelor}

Evoluția omului și asigurarea siguranței alimentare este indispensabil legată de funcționalitatea florei, îndeosebi a culturilor agricole. Plantele, grație proceselor fotosintetice, asigură omenirea cu oxigenul necesar pentru respirație, precum şi multe procese biogeochimice importante. Culturile agricole reprezintă $80 \%$ din cantitatea de alimente pe care le consumăm și împreună furnizează $98 \%$ din oxigenul pe care îl respirăm. Paralel cu aceasta poluarea pune în pericol existenţa a numeroase plante şi animale. Pe acest fond, Organizaţia Naţiunilor Unite prin intermediul Rezoluţiei 73/252, adoptată la 20 decembrie 2018 de Asamblea Generală a declarat anul 2020 "Anul internaţional al sănătăţii plantelor (IYPH)" [3].

Odată cu evoluția cercetărilor în domeniul cultivării plantelor au apărut boli și dăunători ce pun în pericol obținerea unor producții stabile. Cu toate acestea, adesea nu ne gândim cum să facem să le păstrăm sănătoase, ceea ce ar putea duce la rezultate devastatoare. FAO estimează că până la 40 de procente din culturile care generează hrană se pierd anual din cauza dăunătorilor şi bolilor. Astfel, milioane de oameni rămân fără hrană, agricultura fiind şi o sursă primară de venituri pentru comunităţile umane [11].

În fiecare an, până la $40 \%$ din culturile globale se pierd din cauza dăunătorilor și bolilor plantelor, iar pierderile anuale în comerțul agricol mondial sunt de peste 220 de miliarde de dolari. Tot aici pot fi însumate și milioane de oameni care nu au ce mânca, dar și afectarea gravă a veniturilor comunităților rurale, unde singura sursă de venit este reprezentată de activitatea agricolă desfășurată [5].

Schimbările climatice şi activităţile omului au afectat ecosistemele, reducând biodiversitatea şi creând noi nişe unde bolile plantelor se dezvoltă. În acelaşi timp, călătoriile şi comerţul internaţional s-au triplat în ultimul deceniu, acest lucru accelerând răspândirea agenților fitopatogeni pe Terra şi provocând pagube pentru plantele native şi mediu. Protejarea plantelor de organismele dăunătoare este mult mai rentabilă decât intervenţia de urgenţă când plantele sunt în starea manifestării simptomelor şi pierderilor economice. Dăunătorii şi agenții patogeni ai bolilor sunt adesea imposibil de eradicat odată ce s-au instalat, iar gestionarea lor este costisitoare şi necesită timp. Activităţile de prevenire sunt inevitabile pentru reducerea impactului devastator al dăunătorilor şi bolilor asupra agriculturii, mijloacelor de subzistenţă şi a securităţii alimentare, iar populaţia Terrei joacă un rol important.

Abordarea ecosistemică combină diferite strategii şi practici de management pentru dezvoltarea culturilor sănătoase în acelaşi timp cu minimizarea utilizării pesticidelor. Evitarea aplicării pesticidelor atunci când trebuie eliminate organismele dăunătoare nu numai că reduc pierderile şi protejează culturile agricole şi mediul înconjurător, dar apără şi insectele 
polenizatoare, inamicii naturali ai patogenilor și dăunătorilor, organismele benefice, precum şi oamenii şi organismele care depind de plante $[2,6,7]$.

\section{Schimbarea paradigmei protecției plantelor - rezultat al frământărilor omenirii și cale de soluționare a problemelor agriculturii, sănătății publice și protecției mediului înconjurător}

Periodic comunitatea științifică trece prin ceea ce se numește o modificare de paradigmă. Aceasta se întâmplă când una dintre presupunerile noastre fundamentale de bază se modifică, aşa cum s-a întâmplat de mai multe ori la schimbările pozițiilor conceptuale asupra universului și asupra altor fenomene generale. Fiecare dintre aceste modificări de paradigmă au nevoie de timp pentru a fi acceptate de savanţi şi de mai mult timp pentru a fi acceptate de societatea umană.

Pornind de la dinamica și tendințele evoluției populației Terrei care, fiind într-o creștere continuă, a depășit 7,5 miliarde de locuitori și perspectiva atingerii a 9 mlrd în 2040 și 10 mlrd în 2060, devine tot mai stringentă necesitatea activizării măsurilor de fortificare a securității alimentare. Pe fundalul acestei perspective, daunele cauzate de organismele dăunătoare constituie $25-30 \%$, iar în condiţiile dezvoltării epifitotice a patogenilor şi invaziei vertiginoase a dăunătorilor şi buruienilor, pierderile de recoltă depăşesc nivelul de 50-60\% sau compromit complet culturile agricole. Explicarea fenomenelor și tendințelor sumbre de dezvoltare a plantelor de cultură, ca furnizor principal de produse alimentare pentru omenire, sunt strâns legate de îngrijorările omenirii privind asigurarea securităţii alimentare și siguranței alimentelor și se reflectă în decizia Organizaţiei Naţiunilor Unite pentru Alimentaţie şi Agricultură (FAO) privind declararea anul 2020 "Anul Internaţional al Sănătăţii Plantelor" [9].

În baza practicii cercetării şi a consensului din știință "Protecția Plantelor”, care deși a atins stadiul maturităţii, dar nu dispune de argumentări teoretice și aplicative suficiente pentru soluționarea problemelor, care ating și societatea, devine rațională schimbarea paradigmei prin introducerea sintagmei "Sănătatea Plantelor". Drept rezultat al argumentării corecte privind schimbarea disciplinei științifice ajunse în acest stadiu când nu mai poate fi condusă de abordările teoretice şi metodologice specifice protecției plantelor și necesită schimbarea poziției generale a paradigmei prin aplicarea abordărilor încadrate în sintagma "Sănătatea plantelor".

Paradigma nouă se bazează pe realizări științifice recunoscute, care pentru o perioadă a dezvoltării domeniului investigat, va oferi abordări originale ale problemelor, dar şi soluții model comunități de specialiști, precum și comunităților sociale. Drept rezultat vor fi oferite modele de formulare şi rezolvare de probleme cercetătorilor, practicienilor și maselor largi ale populației, care cuprind elemente de natură teoretică, instrumentală şi metodologică și diverse soluții practice [11].

Protecția culturilor agricole de agenţii fitosanitari și păstrarea capacităților de sănătate a lor este mult mai rentabilă decât intervenţia de urgenţă când plantele se află la un grad înalt de atac. Dăunătorii şi agenții patogeni ai bolilor sunt adesea imposibil de eradicat odată ce sau instalat în agrocenozele culturilor agricole, iar gestionarea lor este costisitoare şi necesită timp. Prevenirea este esenţială pentru evitarea impactului devastator al dăunătorilor şi bolilor asupra agriculturii, mijloacelor de subzistenţă, a securităţii alimentare şi securităţii alimentelor.

Abordarea sistemică combină diferite strategii şi practici de management pentru dezvoltarea culturilor sănătoase concomitent cu minimizarea utilizării pesticidelor. Evitarea aplicării pesticidelor pentru eliminarea organismelor dăunătoare nu numai că contribuie la 
ameliorarea stării fitosanitare și reducerea presei pesticide, dar și protejează mediul înconjurător, apărând organismele utile, îndeosebi insectele entomofage și polenizatoare, care reprezintă inamici naturali ai organismelor dăunătoare [12].

FAO mai trasează câteva responsabilităţi ce revin în sarcina oamenilor: să evităm transportarea plantelor şi a produselor vegetale atunci când călătorim peste hotare; persoanele angajate în industriile de transport trebuie să se asigure că navele, aeronavele, camioanele şi trenurile nu transportă dăunători sau boli în zone noi; guvernele trebuie să-şi crească susţinerea la nivel naţional sau regional pentru organizaţiile de protecţie a plantelor din prima linie de apărare [8].

\section{Măsurile de recunoaștere a priorităților globale și de sensibilizare a comunității umane spre asigurarea sănătății plantelor}

Este de așteptat ca Anul Internațional al Sănătății Plantelor să sporească gradul de conștientizare al publicului și factorilor de decizie in ceea ce privește importanța plantelor sănătoase și necesitatea de a le proteja pentru a atinge obiectivele ONU de dezvoltare durabila. Actualmente o bună parte din culturile agricole sunt pierdute anual din cauza organismelor patogene, valoarea pierderilor economice constituind $220 \mathrm{mlrd}$ USD anual.

Recunoașterea priorităților globale a activităților privind asigurarea sănătății plantelor este determinată de reducerea biodiversității florei spontane și a culturilor agricole manifestată în triplarea în ultimul deceniu al numărului de călătorii şi a comerțului internaţional, ceea ce accelerează răspândirea dăunătorilor și agenților patogeni ai bolilor şi provoacă pagube enorme pentru culturile agricole şi mediul înconjurător. Astfel dăunătorii şi agenții patogeni ai bolilor sunt adesea imposibil de eradicat odată cu pătrunderea în componența agroecosistemelor, iar gestionarea lor devine foarte costisitoare şi necesită timp îndelungat pentru realizarea unei game complexe de măsuri de carantină fitosanitară [15].

În temeiul cunoștințelor biogeocenotice și pentru reglarea densității populațiilor de organisme dăunătoare devin prioritare măsurile de minimizare a aplicării pesticidelor, asigurând sănătatea plantelor prin implementarea activităților orientate la:

- evitarea transportării plantelor şi a produselor vegetale în timpul călătoriilor peste hotare și asigurarea industriilor de transport cu nave, aeronave, camioane şi trenuri cu posibilități de control și excludere a dăunătorilor și agenților patogeni ai bolilor;

- $\quad$ sporirea susţinerii organizaţiilor de protecţie a plantelor din prima linie de apărare de către guverne la nivel naţional sau regional.

În așa mod, devine evident că deși impactul organismelor dăunătoare asupra plantelor de cultură crește permanent, iar resursele aplicate în acest sens sunt limitate, se fortifică speranța că Anul Internațional al Sănătății Plantelor va contribui la o colaborare globală pentru a sprijini politicile fitosanitare la toate nivelurile, ceea ce va fortifica în mod semnificativ dezvoltarea durabilă a comunității umane.

Finlanda a propus pentru prima data proclamarea anului la organismul de conducere al Organizației Internaționale pentru Protecția Plantelor (OIPP) in 2015, primind sprijinul internațional in cadrul Comisiei privind masurile fitosanitare, al FAO si al celei de-a 73-a Adunări Generale a ONU. Este cunoscut că dăunătorii si agenții patogeni ai bolilor nu poarta pașapoarte si nu respectă cerințele de imigrare si, prin urmare, prevenirea răspândirii acestor organisme este o problema internațională care necesita colaborarea tuturor statelor. Plantele sănătoase reprezintă baza fundamentală pentru toate functiile ecosistemelor si securitatea alimentară. Susținerea sănătății plantelor protejează mediul si biodiversitatea împotriva organismelor dăunătoare, abordează efectele schimbărilor climatice și sprijină eforturile de a stopa foametea, malnutriția și sărăcia [3]. 
În contextul Anului Internațional al Sănătății Plantelor, la nivel global au fost și vor mai fi organizate mai multe evenimente. Cea mai importantă a fost cea de-a 15-a Sesiune a Comisiei pentru Măsuri Fitosanitare, care a avut loc la Roma (30 martie - 3 aprilie 2020) şi Conferința Internațională „Protejarea sănătăţii plantelor într-o lume în schimbare”, preconizată pentru perioada 5-8 octombrie 2020 și care se va desfășura la Helsinki.

\section{Cum Republica Moldova promovează dezideratele anului sănătăţii plantelor}

Deși agricultura Republicii Moldova pe parcursul mai multor ani a jucat un rol important în promovarea inovatiiilor agricole, în ultimele decenii se înregistrează o reducere permanentă a tempourilor de implementare a tehnologiilor moderne orientate la păstrarea sănătății plantelor și protecția mediului înconjurător. În calitate de membru a Convenției Internaționale pentru Protecția Plantelor și a multor foruri mondiale, regionale și naționale, Republicii Moldova devine responsabilă de implementarea măsurilor stipulate, inclusiv de promovare a Anului Internațional al Sănătății Plantelor.

Asigurarea executării dezideratelor conținute în documentele internaţionale pentru agricultura Republicii Moldova este indispensabil legată de respectarea măsurilor de protecție a plantelor, începând cu măsurile de carantină fitosanitară şi continuând cu operațiile incluse în hărțile tehnologice de producere a fiecărei culturi agricole. Deosebit de importante devin măsurile necesare pentru stricta respectare a rigorilor fitosanitare de către participanții la turismul și comerțul internațional, deoarece aceștia participă activ la răspândirea agenților fitosanitari $[1,4]$.

Succesul programelor de implementare a măsurilor Anului Internațional al Sănătății Plantelor este indispensabil legat de pregătirea și promovarea măsurilor, printre care un loc deosebit revine difuzării informației și comunicării prin intermediul organelor de informare în masă despre sănătatea plantelor pe tot parcursul anului 2020 și nu numai, precum şi participarea activă la iniţiativele de protecție a resurselor naturale și de promovare a mijloacelor ecologic inofensive în sistemele de agricultură convențională și ecologică.

Un rol deosebit în promovarea acestei inițiative valoroase revine întreprinderilor agricole, fermierilor și tuturor celor cointeresaţi în sectorul fitotehnic și devin direct obligaţi în asigurarea sănătății plantelor și executarea următoarelor măsuri:

- Stoparea și crearea condițiilor de împiedicare a răspândirii dăunătorilor și agenților patogeni ai bolilor, respectând mijloacele încadrate în fișele tehnologice și folosind doar semințe și răsaduri lipsite de agenți fitosanitari;

- Monitorizarea regulată a propriei ferme și a dezvoltării organismelor dăunătoare prin introducerea managementul ecologic, inclusiv a mijloacelor ecologic inofensive și activizarea elementelor naturale utile în reglarea densității populațiilor de organisme dăunătoare;

- Utilizarea tehnologiilor digitale moderne și a agriculturii de precizie pentru a avea acces la informații privind prognozarea și semnalizarea dezvoltării dăunătorilor și a agenților patogeni ai bolilor culturilor agricole.

FAO mai trasează diverse responsabilităţi ce necesită a fi respectate de către fiecare reprezentant al comunității mondiale: evitarea transportării plantelor şi a produselor vegetale atunci când călătorim peste hotare; persoanele angajate în industriile de transport trebuie să se asigure că navele, aeronavele, camioanele şi trenurile nu transportă dăunători sau boli în zone noi; guvernele trebuie să-şi crească susținerea la nivel național sau regional.

Institutul de Genetică, Fiziologie şi Protecţie a Plantelor pe parcursul mai multor ani efectuează cercetări și a înregistrat rezultate remarcabile în domeniul elaborării și aplicării mijloacelor biologice (entomofagi, preparate biologice și substanțe biologic active) pentru sistemele de agricultură convențională și ecologică, iar în lumina deciziei FAO a planificat 
organizarea Simpozionului Științific Internațional „Protecția Plantelor - Realizări şi Perspective", care î-și va desfășura lucrările la 27-28 octombrie 2020.

Drept consecință a implementării procedeelor tehnologice de producere și aplicare a mijloacelor biologice de protecție a plantelor se înregistrează păstrarea diversității biologice, crearea condițiilor pentru activitatea omului și de funcționare a elementelor mediului înconjurător, care reprezintă suportul principal în promovarea măsurilor dedicate sănătății plantelor [13].

\section{Concluzii}

La nivel internațional, anul 2020 este dedicat sănătății plantelor. FAO a declarat acest an, Anul Internaţional al Sănătății Plantelor cu scopul creșterii gradului de conștientizare a producătorilor și consumatorilor privind modul în care asigurarea sănătății plantelor poate ajuta la scăderea gradului de înfometare al populației, reducerea sărăciei, protejarea mediului înconjurător și stimularea dezvoltării economice. Având ca obiectiv creșterea gradului de conștientizare a rolului protecției plantelor în asigurarea sănătății plantelor, evenimentul va spori contribuția agriculturii la securitatea alimentară în condițiile creșterii continue a populației.

Întru asigurarea necesităților agriculturii Republicii Moldova, îndeosebi a sectorului orientat la obținerea și procesarea produselor agroalimentare ecologice, se înregistrează rezultate semnificative de extindere a spectrului de mijloace de protecție biologică atât în agricultura convențională, cât și cea ecologică.

În condițiile dominării protecției chimice devine necesară toleranță zero față de produsele contrafăcute, prevenirea poluării mediului înconjurător, implementarea echipamentelor moderne de protecție pentru aplicarea tratamentelor, promovarea utilizării responsabile a produselor ecologic inofensive de protecție a plantelor în contextul agriculturii durabile, care combină respectul pentru sănătatea oamenilor cu grija pentru un mediu sănătos, satisfăcând cererea pentru produsele agricole și siguranței alimentelor.

\section{Bibliografie}

1. Biological control of pest using trichogramma: current status and perspectives, edited by S.B. Vinson, S.M. Greenberg, T.-X. Liu, A. Rao, L.F Volosciuk. Northwest A\&F University Press, China, 2016. 496 p.

2. Doudna J.A., Charpentier E. Genome editing. The new frontier of genome engineering with CRISPR-Cas9. Science, 2014. 346: 1258096.

3. FAO. International Year of Plant Health, 2020: Communication guide. 2019. Rome. $31 \mathrm{p}$.

4. Global Organic Statistics 2014 and Organic 3.0. Growing Organic Agriculture Sector Explores its Future. FIBL, IFOAM. 2014. p. 1-8.

5. International assessment of agricultural knowledge, science and technology for development: global report / edited by Beverly D. McIntyre et al. W., 2009. 606 p.

6. Megha K., Kaur G. S. Ecological impact of genetically modified crops. Res. J. of Recent Sci., 2013, 2, p. 1-4.

7. National Academies of Sciences, Engineering, and Medicine. Genetically Engineered Crops: Experiences and Prospects. National Academies Press. 2016. 606 p.

8. Niculescu M., Lavalette G. Strategie de creștere. București. Ed.economică. 1999. 480 p.

9. Toncea I., Simion E., Ioniţă Niţu G., Alexandrescu D., Toncea V. A. Manual de agricultură ecologică. București, 2012, 360 p. 

4 p.

10. United Nations. International Year of Plant Health (IYPH). Resolution 73/252, 2018.

11. Voloșciuc Л.T. Probleme ecologice în agricultură. Chişinău: Bons Offices, 2009, $264 \mathrm{p}$.

12. Voloșciuc L.T. Soluționarea problemelor de protecție a plantelor în agricultura ecologică. Noosfera. 2014, nr. 10-11. p.151-158.

13. Voloșciuc L.T., Josu Veronica. Conceptul de agricultură ecologică - suport al agriculturii durabile în Republica Moldova. Noosfera. 2016. Nr. 17. p. 89-98.

14. Voloșciuc Л.T. Producerea culturilor cerealiere și leguminoase pentru boabe în sistem ecologic. Chișinău. IGFPP. 2019. 92 p.

15. Voloşciuc L. Rolul şi Locul OMG în Soluţionarea Problemelor Fitosanitare. Akademos. 1/2020. p.33-38.

16. Willer Helga. The adventure of collecting data on organic agriculture worldwide. The World of Organic Agriculture. BIOFACH Congress. Nürnberg, 2019. 32 p.

17. Доспехов Б.А. Методика полевого опыта // М., Агропромиздат, 1989, 313 с.

18. Савинов А.Б. Новая популяционная парадигма: популяция как симбиотическая самоуправляемая система. ВЕСТНИК Нижегородского университета им. Н.И. Лобачевского. Биология. Выпуск 1 (9). Материалы VIII Всероссийского популяционного семинара «Популяции в пространстве и времени» (11-15 апреля 2005. Нижний Новгород. 2005. с. 181-196. 